\title{
Silicone Implants Biocompatibility after Latissimus Dorsi Flap Reconstruction
}

\author{
Tatsiana Paliyenka and Jing Han* \\ Breast Surgery Department, Shanghai East Hospital Affiliated to Tongji University, China \\ *Corresponding author: Dr. Jing Han, Breast Surgery Department, Shanghai East Hospital, Shanghai, 200120 China. \\ E-mail: kristall1341@foxmail.com
}

ARTICLE INFO

Received: 唪 March 27, 2019

Published: 幽 April 03, 2019

Citation: Tatsiana Paliyenka, Jing Han. Silicone Implants Biocompatibility after Latissimus Dorsi Flap Reconstruction. Biomed J Sci \& Tech Res 16(4)-2019. BJSTR. MS.ID.002896.

Keywords: Breast Reconstruction; Latissimus Dorsi Flap; Breast Implants; Capsular Contracture; Review
ABSTRACT

Background: There are many implications to the ever-growing intimate and necessary involvement of industry in biomedical research for breast reconstruction surgery.

Main Body: The major objective of this study to investigate Capsular Contracture (CC) which remains a concern in long-term transplantation and most common complications following silicone implants placement after Latissimus Dorsi flap (LDF) breast reconstruction surgery. CC formation, with special attention paid to immunological and inflammatory reasons, estrogen receptors in peri-prosthetic tissue development, as well as actual prophylactic strategies after breast reconstruction surgery were all investigated. This review summarizes and explores these trends of the association between conflicts of interest and study outcomes in oncoplastic surgery. In addition, we explored whether studies have identified microbial biofilms on various implantable materials and Foreign Body Reaction (FBR).

Conclusion: We envision using predictive outcomes of this study to further tailor breast reconstruction procedures according to patients' needs. Moreover, the results can help us to reach the best possible patient counseling, treatment, and care.

\section{Introduction}

First of all, breast cancer is an unpleasant and sometimes devastating event in a woman's life. The goal of oncoplastic breast surgery is restore the appearance of the breast and improve patient quality of life. To use of flap reconstruction of breast following mastectomy is considered by many surgeons as the gold standard [1]. Today, advances of this technique are that it is reliable, predictable, relatively easy to perform various contours and landmarks of the breast, which has resulted in improvement of aesthetic results [2]. The Latissimus Dorsi Musculocutaneous Flap (LDF) plays and important part of breast reconstruction history. This technique has been studied by many researches since its introduction by Iginio Tansini in 1896 [3]. Previous studies have reported, the great used of LD flap procedures in both the delayed or immediate reconstruction [4], with or without implants [5] and as procedure for small volume reconstructions [6]. This research extends our knowledge of the patients who is candidate for LDF, operation techniques, most common complications following breast reconstruction surgery and further investigation for the future concern. Breast reconstruction with flap is safe as total mastectomy for early-stage patients and even in stage III patients [7]. These findings suggest that LDF is the first line for obese patients [8] and the patients with insufficient abdominal fat [9], resistant to the deleterious effects of tobacco use and diabetes in wound healing, which makes it an excellent choice in these high-risk of necrosis and secure for reconstruction in the event of damage to the skin envelope [10].

\section{Latissimus Dorsi Flap Postoperative Management}

Debate continues about the best strategies for the management of operative technique positioning cushion and skin-sparing mastectomy [11], scar transparency [12], the flap transferring with preserved thoracodorsal nerve and artery [1,13]; simple and reliable nipple reconstruction with badge flaps combined intradermal tattooing for the nipple areola, which it gives the patient good psycho- 
logical support and provides a very good result aesthetically with an inconspicuous scar at the donor site [14]. Recently, researches have shown an increased interest in endoscopic-assisted LD flap transposition. This technique leaves less scarring on the back than conventional LD flap transposition [15] due to the limitation accessibility and difficulty of harvesting [16].

However, repositioning the latissimus dorsi muscle may result in moderate-to-severe postoperative pain [13]. This result may be explained by the fact of wound dehiscence, skin necrosis and seroma formation by damaging lymph vessels and inflammatory exudates caused by more extensive subcutaneous and muscle dissection [17].

The whole thickness of the muscle is mobilized and detached distally; attempts to spare some of it to retain function simply lead to atrophy from denervation $[8,18]$. Resulting from tissue oxygenation [19], hypertension and hyperlipidemia will lead to delay wound healing and vasopressors [20]. Pressure garments [21] or fibrin sealants; limited use of electrocautery, long-term drainage [22] will minimizing seroma formation. LD flap reconstruction can result in weakness and reduced mobility in shoulder function [23] within postoperative time, but in long term recovery detected near normal [24] with no significant loss of range of motion, strength, or pain in the shoulder at 1 year [14].

\section{Implants Placement Complications}

The main contribution of breast volume components are the LD muscle, its skin paddle, and in most cases use of silicone implant [25], which is placed under the muscle alone or with a tissue expander and to expand the skin to provide adequate skin coverage of the correctly sized implant [21]. Risk of bacterial infection, radiotherapy complications $[6,10]$, chronic wound damage and inflammatory response [26], closely related to patient sensitivity to position of implant placement. Due to physiological inertness and low toxicity, silicone implants are biomaterials [27] that are frequently used in the medical industry. But according to some recent research, the most common fibrosis reaction is the Foreign Body Reaction (FBR) [28], which occurs when biomaterials are implanted. The fibrotic response to biomaterials is caused by an immune reaction, this occurs through adaptive immune reaction in 6 stages:

a) Blood-biomaterial interaction is initialized by the leakage of blood at the wound site when an implant inserted and results in the surface bonding of proteins in the blood [29].

b) In provisional matrix formation high-affinity proteins (i.e., fibrinogen, kininogen, fibronectin, and vitronectin) combine to form a provisional matrix [30] various inflammatory cells (i.e., neutrophils, eosinophils, basophils and others).

c) In acute inflammation, neutrophils and eosinophils play a major role in this early inflammatory reaction and activate cells through the expression of various factors (i.e., TNF- $\alpha$, interleukin family, IFN- $\gamma$ ) [31]. d) Chronic inflammation usually occurs for 2-3 weeks, during which the cytokines induce collagen synthesis in the periphery of biomaterials are primarily expressed [32].

e) Foreign body giant cell formation during chronic inflammation generate fibrosis, determines the presence or absence of fibrosis at the capsule formation stage, and regulates fibrosis severity by changing the activity of the factors according to the characteristics of the biomaterials [33], and

f) Fibrous capsule formation, such fibrous scar tissue that surrounds a foreign body and CC [34,35].

The complex capsular factors determined capsular contracture grade incidence with covered polyurethane- or silicone-textured surface implants [5]. Therefore, the word "biocompatibility" has used to describe the overall biological innocuousness of silicone in the respective studies [36]. The hormonal status was recently linked to these processes as well, such as post-operative pregnancy to be a risk factor for capsular contracture. Estradiol is a potent mediator of angiogenesis: estrogen receptors are involved in the regulation of Vascular Endothelial Growth Factor (VEGF) pathways, induce TGF- $\beta 1$ production and myofibroblasts differentiation [37].

\section{Improving Satisfaction in Breast Reconstruction}

According to the multiple studies, one method for improving postoperative skin flap-based complications in breast reconstruction is the use of Indocyanine Green (ICG) soluble dye angiography for real-time imaging and assessment of blood flow and tissue perfusion perioperatively. ICG is eliminated by the liver and excreted in bile [38]. The main reason of Indocyanine Green angiography use is predicting postoperative flap necrosis [39] and delayed wound healing through identification of hypoperfusion and debridement of compromised tissue [40]. Despite the higher stakes for potential necrotic skin flaps in expander- or implantbased reconstruction patients, especially for those with thinner mastectomy flaps, autologous reconstruction was associated with an increase in Indocyanine Green angiography use [41]. Last of all, patient expectations and the decision-making process play a key role in determining satisfaction with breast reconstruction following mastectomy [42]. The breast cancer conservative treatment cosmetic results (BCCT.core) provides an overall aesthetic assessment based on breast symmetry, skin color changes, and surgical scar appearance on photographs of women who have undergone breast-conserving surgery with or without radiotherapy [43]. The BREAST-Q is a newly developed, PatientReported Outcome Measure (PROM) that was specifically designed to measure quality of life and patient satisfaction among breast surgery patients [44]. This finding suggest that patients undergo mastectomy without reconstruction can experience psychosocial disturbances and problems with body image and sexuality and provides psychosocial and quality of life benefits $[7,45]$.

Conclusion Although we have shown both benefits and drawbacks to this approach, we believe that breast reconstruction 
have improved remarkably over the past years. Many types of procedures are now available for reconstructing the breast after a complete or partial mastectomy. Several papers have shown that CC occurs due to bacterial presence as well as an FBR to silicone and confirmed that bacterial colonization is closely related to highgrade capsular contracture. Therefore, fibrous tissue deposition and remodeling following implant placement depend on several factors, such as recruitment of inflammatory cells, trans differentiation of fibroblasts into myofibroblasts, collagen deposition and neoangiogenesis. In oncological and reconstructive breast surgery, ICG is used for sentinel lymph node identification, to predict mastectomy skin flap necrosis, to assess the perfusion of free flaps, especially for high-risk patients who smoke, obese, diabetes, in autologous reconstruction and for diagnosis and treatment of upper limb secondary lymphedema. In spite of worldwide efforts, to date, the genetic, molecular, immunological and environmental factors involved in the physiological response to the foreign body. The hormonal status was recently linked to these processes. Each procedure is associated with specific potential complications and it is here where careful patient evaluation is necessary to choose the "right" procedure for the individual patient.

\section{References}

1. Nahabedian MY, Patel K (2016) Autologous flap breast reconstruction: Surgical algorithm and patient selection. J Surgical Oncol 113(8): 865874.

2. Ishii N, Ando J, Shimizu Y, Kishi K (2018) A novel technique for large and ptotic breast reconstruction using a latissimus dorsi myocutaneous flap set at the posterior aspect, combined with a silicone implant, following tissue expander surgery. Arch Plast Surg 45(5): 484-489.

3. Maxwell GP (1980) Iginio Tansini and the origin of the latissimus dorsi musculocutaneous flap. Plast Reconstr Surg 65(5): 686-692.

4. Wong A, Snook K, Brennan M, Flitcroft K, Tucker M, et al. (2014) Increasing breast reconstruction rates by offering more women a choice. ANZ J Surg 84(1-2): 31-36.

5. Dutra Alexandre Katalinic, Neto Miguel Sabino, Garcia Élvio Bueno, Veiga Daniela Francescato, Domingues Maurício Castello, et al. (2009) The role of transverse latissimus dorsi musculocutaneous flap immediate breast reconstruction. European J Plastic Sur 32(6): 293-299.

6. DeLong MR, Tandon VJ, Rudkin GH, Da Lio AL (2017) Latissimus Dorsi Flap Breast Reconstruction-A Nationwide Inpatient Sample Review. Ann Plast Surg 78(5 Suppl 4): S185-S188.

7. Du Z, Zhou Y, Chen J, Long Q, Lü Q (2018) Retrospective observational study of breast reconstruction with extended latissimus dorsi flap following skin-sparing mastectomy. Medicine (Baltimore) 97(31): e10936.

8. Sood R, Easow JM, Konopka G, Panthaki ZJ (2018) Latissimus Dorsi Flap in Breast Reconstruction: Recent Innovations in the Workhorse Flap. Cancer Control 25(1): 1073274817744638.

9. Kazzazi F, Ching RC, Malata CM (2018) Postmastectomy Breast Reconstruction With the Totally Autologous Latissimus Dorsi Flap in the Thin, Small-Breasted Woman: Give It More Thought! Eplasty 18: e13.

10. Pechevy L, Carloni R, Guerid S, Vincent PL, Toussoun G, et al. (2017) Skin-Reducing Mastectomy in Immediate Reconstruction: How to Limit Complications and Failures. Aesthet Surg J 37(6): 665-677.

11. Lai HW, Wang CC, Lai YC, Chen CJ, Lin SL, et al. (2019) The learning curve of robotic nipple sparing mastectomy for breast cancer: An analysis of consecutive 39 procedures with cumulative sum plot. Eur J Surg Oncol 45(2): 125-133.

12. Steffen CM, Day KM, Gilson AJ, Zoog E, Brzezienski MA (2018) Vertical Inset of the Latissimus Dorsi Flap Improves Reconstruction Aesthetics by Reducing Scar Burden in the "Social Breast". Ann Plast Surg 80(6S Suppl 6): S365-s371.

13. Cook J, Waughtel J, Brooks C, Hardin D, Hwee YK, et al. (2017) The Muscle-sparing latissimus dorsi flap for breast reconstruction: a retrospective review of 126 consecutive flaps. Ann Plast Surg 78(6S Suppl 5): S263-s268.

14. Chiang IH, Wang CH, Tzeng YS, Chiao HY, Chou CY, et al. (2017) Breast Reconstruction Using Pedicled Latissimus Dorsi Myocutaneous Flaps in Asian Patients With Small Breasts. Ann Plast Surg 78(3 Suppl 2): S95-s101

15. Missana MC, Pomel C (2007) Endoscopic latissimus dorsi flap harvesting. Am J Surg 194(2): 164-169.

16. Shin ES, Kim HI, Song SY, Lew DH, Lee DW (2018) Selection of oncoplastic surgical technique in Asian breast cancer patients. Arch Plast Surg 45(1): 37-44

17. Sowa Y, Numajiri T, Nakatsukasa K, Sakaguchi K, Taguchi T (2017) Comparison of morbidity-related seroma formation following conventional latissimus dorsi flap versus muscle-sparing latissimus dorsi flap breast reconstruction. Ann Surg Treat Res 93(3): 119-124.

18. Olivari N (1976) The latissimus flap. Br J Plast Surg 29(2): 126-128.

19. Guo S, LA Dipietro (2010) Factors affecting wound healing. J Dent Res 89(3): 219-229.

20. Nelson JA, Chung CU, Fischer JP, Kanchwala SK, Serletti JM, et al. (2015) Wound healing complications after autologous breast reconstruction: a model to predict risk. J Plast Reconstr Aesthet Surg 68(4): 53153-9.

21. Højvig JB, Bonde CT (2015) Breast reconstruction using a latissimus dorsi flap after mastectomy. Dan Med J 62(12): A5155.

22. Landis LV, Brzezienski MA, Gao C, Lee T (2016) The Effect of progressivetension closure on donor site seroma formation in delayed latissimus dorsi flaps for breast reconstruction. Ann Plast Surg 76(2): 170-173.

23. Steffenssen MCW, Kristiansen AH, Damsgaard TE (2019) A Systematic Review and Meta-analysis of Functional Shoulder Impairment After Latissimus Dorsi Breast Reconstruction. Ann Plast Surg 82(1): 116-127.

24. Koh E, Watson DI, Dean NR (2018) Quality of life and shoulder function after latissimus dorsi breast reconstruction. J Plast Reconstr Aesthet Surg 71(9): 1317-1323.

25. Feng J, Pardoe CI, Mota AM, Chui CH, Tan BK (2016) Two-stage latissimus dorsi flap with implant for unilateral breast reconstruction: getting the size right. Arch Plast Surg 43(2): 197-203.

26. Niddam J, Luciano Vidal, Barbara Hersant, Jean Paul Meningaud (2016) Primary fat grafting to the pectoralis muscle during latissimus dorsi breast reconstruction. Plast Reconstr Surg Glob Open 4(11): e1059.

27. Williams DF (2009) On the nature of biomaterials. Biomaterials 30(30): 5897-5909.

28. Ajdic D, Zoghbi Y, Gerth D, Panthaki ZJ, Thaller S (2016) The Relationship of bacterial biofilms and capsular contracture in breast implants. Aesthet Surg J 36(3): 297-309.

29. Anderson JM, Rodriguez A, Chang DT (2008) Foreign body reaction to biomaterials. Semin Immunol 20(2): 86-100.

30. Davis GE, Senger DR (2005) Endothelial extracellular matrix: biosynthesis, remodeling and functions during vascular morphogenesis and neovessel stabilization. Circ Res 97(11): 1093-107.

31. Feghali CA, Wright TM (1997) Cytokines in acute and chronic inflammation. Front Biosci 2: d12-26. 
32. Chaudhary NI, Roth GJ, Hilberg F, Müller Quernheim J, Prasse A, et al., (2007) Inhibition of PDGF, VEGF and FGF signalling attenuates fibrosis Eur Respir J 29(5): 976-985.

33. Sheikh Z, Brooks PJ, Barzilay O, Fine N, Glogauer M (2015) Macrophages, Foreign Body Giant Cells and Their Response to Implantable Biomaterials. Materials (Basel) 8(9): 5671-5701.

34. Rieger UM, Mesina J, Kalbermatten DF, Haug M, Frey HP, et al. (2013) Bacterial biofilms and capsular contracture in patients with breast implants. Br J Surg 100(6): 768-774.

35. Vieira VJ, D’Acampora A, Neves FS, Mendes PR, Vasconcellos ZA, et al (2016) Capsular Contracture In Silicone Breast Implants: Insights From Rat Models. An Acad Bras Cienc 88(3): 1459-1470.

36. Steiert AE, Boyce M, Sorg H (2013) Capsular contracture by silicone breast implants: Possible causes, biocompatibility and prophylactic strategies 6: 211-218.

37. Dancey A, Nassimizadeh A, Levick P (2012) Capsular contracture - what are the risk factors? a 14 year series of 1400 consecutive augmentations. J Plast Reconstr Aesthet Surg 65(2): 213-218.

38. Struk S, Honart JF, Qassemyar Q Leymarie N, Sarfati B, et al. (2018) Use of indocyanine green angiography in oncological and reconstructive breast surgery. Ann Chir Plast Esthet 63(1): 54-61.

39. Diep GK, Marmor S, Kizy S1, Huang JL, Jensen EH, et al. (2019) The use of indocyanine green angiography in postmastectomy reconstruction: Do outcomes improve over time? J Plastic Reconstructive Aesthetic Sur 72(4): 548-554.

\section{ISSN: 2574-1241}

DOI: 10.26717/BJSTR.2019.16.002896

Jing Han. Biomed J Sci \& Tech Res

CC (P) This work is licensed under Creative

Submission Link: https://biomedres.us/submit-manuscript.php
40. Burnier P, Niddam J, Bosc R, Hersant B, Meningaud JP (2017) Indocyanine green applications in plastic surgery: A review of the literature. J Plast Reconstr Aesthet Surg70(6): 814-827.

41. Chattha A, Bucknor A, Chen AD, Lee BT, Lin SJ (2018) Indocyanine Green Angiography Use in Breast Reconstruction: A National Analysis of Outcomes and Cost in 110,320 Patients. Plastic and Reconstructive Sur 141(4): 825-832.

42. Kazzazi F, Haggie R, Forouhi P, Kazzazi N, Wyld L, et al. (2018) A comparison of patient satisfaction (using the BREAST-Q questionnaire) with bilateral breast reconstruction following risk-reducing or therapeutic mastectomy. J Plast Reconstr Aesthet Surg 71(9): 13241331.

43. Kim KD, Kim Z, Kuk JC, Jeong J, Choi KS, et al. (2016) Long-term results of oncoplastic breast surgery with latissimus dorsi flap reconstruction: a pilot study of the objective cosmetic results and patient reported outcome. Ann Surg Treat Res 90(3): 117-123.

44. McCarthy CM, Klassen AF, Cano SJ, Scott A, Vanlaeken N, et al. (2010) Patient satisfaction with postmastectomy breast reconstruction. Cancer 116(24): 5584-5591.

45. Leonardis JM, Diefenbach BJ, Lyons DA, Olinger TA, Giladi AM, et al. (2019) The influence of reconstruction choice and inclusion of radiation therapy on functional shoulder biomechanics in women undergoing mastectomy for breast cancer. Breast Cancer Research Treatment 173(2): 447-453.

$\begin{array}{ll}\text { BIOMEDICAL } & \text { Assets of Publishing with us } \\ \text { RESEARCHES } & \text { - Global archiving of articles } \\ & \text { - Immediate, unrestricted online access } \\ \end{array}$

